advanced one inch during the time that the last blow has advanced 13 inches, and thus the distance between the two blows will be $\mathrm{I} 2$ inches, or one foot. If, therefore, an observer be standing on a railway platform and a railway engine be advancing at full speed whistling as it comes, the interval between the blows will be less than usual, or the note will be shriller than if the engine were at rest. On the other hand, when it has passed the station and is rapidly receding from the observer, the interval will be greater than usual, and the note less shrill.

It is precisely the same with regard to light. If a luminous body emitting rays of definite wave length be moving towards the observer, the wave length will be lessened and the ray pushed forwards to the more refrangible side of the spectrum. If, on the other hand, it be moving from the observer, the wave length will be increased, and the ray pushed backwards to the less refrangible side of the spectrum.

'The only difference between light and sound is that the former moves so fast, that in order to get an appreciable alteration in wave length we must have a luminous body moving from or towards us with velocities much greater than we can produce experimentally, whereas in the case of sound we can make the experiment.

Nevertheless if we go to the surface of the sun, or to the fixed stars, we shall find luminous objects moving from or towards us with velocities sufficiently great to suit our purpose.

Let me now say a few words on the effect produced on some gaseous spectra by increasing the temperature of the gas. It is quite certain that at comparatively low temperatures such spectra are more complicated than they are when the temperature is high. In the former case they frequently present a fluted appearance, while in the latter we have spectra composed of a few bright lines on a dark background.

In some cases an increase of temperature entirely changes the character of the spectrum, so that certain socalled elementary substances may be said to have two or more spectra. In general, however, we have, notwithstanding these remarks, the great feature already mentioned of a persistence of the more permanent spectral lines, more especially in the case of metals, throughout a large temperature range.

By means of spectrum analysis we have discovered the existence of several new elementary metals, all of which are very sparingly distributed.

Bunsen was the first to detect two new elementary metals, coesium and rubidium. Shortly afterwards Crookes discovered thallium, Messrs. Reich and Richter indium, and other elementary metals have since been discovered by the same means.

It is now time that something should be said about the phenomena of absorption. Since gases have small radiating powers, they may naturally be supposed to have small powers of absorption. We know, for instance, how feeble is the absorption of pure air for luminous rays, or even for ordinary heat rays. Tyndall has studied the absorptive power of gases for low temperature heat, and has come to some very interesting conclusions. The following table embodies the results of his experiments:-

Comparative absorption of various gases, each of the pressure of $\mathrm{I}$ inch.

$\begin{array}{lllllllllll}\text { Air } & \ldots & \ldots & \ldots & \ldots & \text { I } & \text { Nitric oxide } & \ldots & \ldots & \text { I590 }\end{array}$

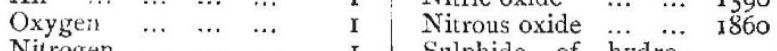
\begin{tabular}{lllll|l} 
Nitrogen & $\ldots$ & $\ldots$ & $\ldots$ & I & Sulphide of hydro-
\end{tabular} \begin{tabular}{ccccc|ccccc} 
Hydrogen & $\ldots$ & $\ldots$ & $\ldots$ & I & gen $\ldots$ & $\ldots$ & $\ldots$ & $\ldots$ & 2 roo \\
Chlorine & $\ldots$ & $\ldots$ & $\ldots$ & 60 & Ammonia & $\ldots$ & $\ldots$ & & 7260
\end{tabular}

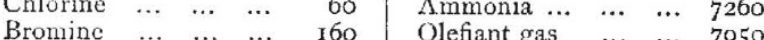
$\begin{array}{lllllll}\text { Hydrobromic acid } & \ldots & 100 & 1005 & \text { Sulphurous acid } & \ldots & 8950 \\ \end{array}$ Carbonic oxide ... $\quad \ldots \quad 75^{\circ}$

By this we learn that the absorptive power of the three permanent simple gases for dark heat is very small, while that of compound gases is very considerable. Tyndall imagines that the molecule of a compound gas may be more inert and less nimble in its vibrations than that of a simple gas. That is to say, the compound molecule will vibrate more slowly than the simple one, and will thus give rise to rays of great wave length; and inasmuch as its absorption and radiation are connected together, it will be peculiarly liable to absorb rays of great wave length.

Its absorption for dark heat may therefore be very great, even although it may appear perfectly transparent for ordinary light rays.

Tyndall has found, as the result of his inquiries, that aqueous vapour absorbs many more dark rays than dry air, and justly concludes that the aqueous vapour present in the atmosphere plays a very important part in terrestrial economy. Being transparent for rays of high temperature it stops but a small proportion of those which come to us from the sun; on the other hand, being comparatively opaque for rays of low temperature, it stops the radiation into space from the surface of the earth. To speak more accurately, it does not absolutely prevent this radiation, but absorbs it and returns as much or nearly as much again. Its action, in fine, is virtually the same as that of a cloud in preventing the refrigeration which accompanies dew. Tyndall remarks that in those regions where the air is very dry the nights are often intolerably cold, owing to this uncompensated radiation into space.

Such regions are those in Central Asia and the great African desert, in the latter of which water can readily be frozen after the sun has sunk. The glass of a greenhouse acts in the same way as the aqueous vapour of the air. It allows the sun's rays freely to penetrate and to heat the air within; but it stops the dark heat of the plants and of the soil from being radiated outwards into free space. Even a loose frame of glass may save the tender blossoms of the peach, and other wall fruit, from being destroyed by nocturnal refrigeration.

\section{BALFOUR STEWART}

\section{(To be continued.)}

\section{NOTES}

ON Monday Prof. Michel Eugene Chevreul entered upon his rooth year. Apart from the fact that among men whose lives have bcen devoted to active scientific research no one has before attained such an age, M. Chevreul stands conspictious for the vast amount of work he has done and for the great practical effect his work has had on the industries of the world. When Dumas in 1852 addressed $M$. Chevreul on the occasion of handing to him the prix of 12,000 francs accorded to him by the Société d'Encouragement pour l'Industrie Nationale, he said :"Le prix consacre l'opinion de l'Europe sur des travaux servent de modèle à tous les chimistes; c'est par centaines des millions qu'il faudrait nombrer les produits qu'on doit à vos découvertes.' More recently, in 1873 , when the award of the Albert medal was made by our Society of Arts, the terms in which the Council expressed the grounds of the award were :- "For his chemical researches, especially in reference to saponification, dyeing, agriculture, and natural history, which for more than half a century have exercised a wide influence on the industrial arts of the world." His scientific work, apart from its commercial outcome, was in this country recognised by the Royal Society as far back as 1826 , when he was clected a foreign associate. In 1857 the Copley medal was awarded to him. Other countrie; have also paid him honour, while the distinctions of his native land have showered upon him. Born in Angers in 1786 (on August 31), where his father was a physician of note, he was but seventeen when he went to Paris to be "manipulateur" in the laboratory of the celebrated Vanquelin. At the age of twenty he published his first chemical paper, and in the next half dozen years he had published more than a score on different subjects. Then began that series of papers (commencing in 1813 ), 
"Recherches chimiques sur plusieurs corps gras, et particulierment sur leurs combinasions avec les alcalis," which extended for many years and were compiled and rearranged in the volume "Les corps gras," issued in 1823 with the dedication "à NicolasLouis Vanquelin, mon maître." In 1824 he was appointed Professor of Chemistry at the famed factory of Gobelins, and the energy and untiring industry which was one characteristic of his work soon accumulated stores of knowledge based on experiment. To exact experiment he attached the bighest importance. He wrote in 1823 " experiment is not chemistry, facts alone do not constitute that science, but we cannot have discoveries without exact experiment." His "Recherches sur la Teinture" is an elaborate work, and his "Moyen de définer et nommer les couleurs" occupies the whole of vol. xxxiii. of the Memoirs of the Institut. It has often been remarked that it is difficult to believe that the Chevreul of "Corps gras" fame and the Chevreul who wrote on colours are one and the same man.

WE regret to have to announce the death, on August 27, of Lieut. L. Brault, of the French navy, who had charge of the Meteorological Service at the Depôt des Cartes et Plans, Paris. M. Brault was the author of several important meteorological works, among which may be specially mentioned one on the circulation of the atmosphere in the North Atlantic and a treatise on astronomy and nautical meteorology. But the great work to which he devoted the larger part of his energy was the preparation and publication of wind charts for the Atlantic, Indian, and Pacific Oceans, a work begun in 1869 and finished in 1880. It consisted of sixteen large charts giving for each quarter, and for squares of $5^{\circ}$, the probable direction and force of wind over those oceans. At the time of his death he was employed in the extraction and tabulation of observations from ships' logs, with the view of publishing monthly charts of various elements as soon as he had collected sufficient data. It is sad to see so able a man cut off in the midst of such useful work.

Mr. George Frederick Armstrong, M.A., F.G.S., C.E., some time Professor of Engineering in the M'Gill University, Montreal, and in the Yorkshire College, Leeds, has been appointed to the Regius Professorship of Engineering in the University of Edinburgh, vacant by the death of Mr. Fleeming Jenkin, LL.D., F.R.S.

THE Queen has been graciously pleased to confer the distinction of Knight Commander of St. Michael and St. George on Mr. John Fowler, C.E.

WE regret to learn that Mr. Trelawney Saunders has retired from the post of geographical assistant to the India Office, a position which he has held with credit to himself and advantage to the public service for the period of seventeen years.

Prof. Calladon, of Geneva, writes a correspondent to the Times, has communicated to the local press a description of a remarkable atmospheric phenomenon which was noticed on August 6. Until after five o'clock p.m. the sky had been calm and serene over all the' valley of the Leman, but at half-past five, albeit the atmosphere above the lake and neighbouring mountain remained remarkably still, vapours were seen at a great height (evidently produced by a strong and warm southwest wind in the upper air) advancing rapidly towards the northeast, and taking the undulatory forms which characterise clouds strongly charged with electricity. At half-past eight the aspect of the sky had become decidedly stormy. The thick cloudmasses were oscillated wildly, albeit their general movement was still from south-west to north-east. After nine o'clock these clouds, drawing away, rendered visible the sheet of cirrus which stretched above them. The cirrus was phosphorescent, and looked as if lighted up by a bright moon. On the north-western horizon the sky along all the chain of the Jura was obscured by thick clouds that from time to time were illuminated by flashes of lightning. It was the same over Mont Galène, above which the lightning played every few minutes. A long black clond stretching from the Dôle to the Galene presented on each side a broad phosphorescent border, and about a quarter past nine there became suddenly visible in that part of the cloud nearest the Jura a luminous centre whence escaped two or three phosphorescent rays pointing towards the south-west. This phenomenon lasted some twenty minutes, and was sufficiently striking to be remarked by many observers. From a quarter past nine to eleven o'clock, moreover, the south-western extremity of Mont Galène was illuminated by a phosphorescent light so intense that its rays were visible from every part of the horizon. The general appearance of this south-west section of the Galène resembled that which is presented by the city of Geneva in thick weather when the mists of evening are lighted up by the gas of the streets. Some rare instances are on record of forests of resinous trees becoming phosphorescent in stormy weather, but the distance from Geneva was too great to enable observers to determine whether the light resulted from the phosphorescence of the fir trees which cover the sides of the Galène or from that of other parts of the mountain. The Central Meteorological Bureau publishes, about eight o'clock every morning daily, accounts of the general condition of the atmosphere throughout Europe, and special reports from twelve stations in Switzerland at eight o'clock a.m. and one o'clock p.m. These reports are received at Geneva on the following day, and those of August 5 and 6 show that on the dates in question there took place a complete change in the atmospheric equilibrium of western Europe, and that the high pressures which for several weeks previously had prevailed over England and the Channel suddenly ceased and gave place to warm, vapour-charged winds from the south-west.

IF original scientific work has been poured forth principally from the old settled countries of Western Europe, it is not a small labour which America seems to be undertaking to thoroughly collect and arrange in available order, not indeed the knowledge, but even the confused heaps of publications from which such knowledge may be painfully extracted. Another valuable catalogue compiled by Dr. H. C. Bolton appears as one of the valuable publications of the Smithsonian Institution. With the unexplained exception of medical science, it contains a list of all the scientific and technical periodicals published in Europe or America since the rise of this literature. It does not include the Procudings and Transactions of Societies already indexed in Mr. S. H. Scudder's Catalogue of Scientific Serials, published in 1879 . As this latter did not contain the titles of technical journals, the two publications are complementary, and together make up a most valuable list to any seeking information; a large proportion of papers, however, neither technical nor Societies' Proceedings, being, of course, found in both. The many large libraries open to the public which form such an item in the wealth of the United States have much assisted in this work, and a list most useful to a student is appended, showing in which of more than 120 of them each publication is to be found. A table, in chronological order, commencing with $\mathrm{I} 728$, is also given, showing during which years each of 500 publications was carried on, and this is provided also with an index by which the place of each in the list may be found. Another index of subjects referring the reader to the principal publications in which each is treated adds greatly to the practical value of the whole work.

DR. Josiah Parsons CoOke has just published a volume entitled "Scientific Culture and other Essays." Science, in 
referring to the volume, says that the most important statcments which are made in these essays are quite independent of the subject-titlc. They should be printed after the manner of certain biblical texts, and displayed on the walls of every collegiate hall in the land. We append a few of these paragraphs:"There is no nobler service than the life of a true teacher; but the mere taskmaster has no right to the teacher's name, and can never attain the teacher's reward" (p. 85). "The teaching which a professorship implies, instead of being a hindrance, ought to be a great stimulus to scientific investigation. Of course this influence is greally impaired, if, as in many of our colleges, the available energies of the teacher are exhausted by the daily routine of instruction, or by outside work required to supplement his meagre salary; but if the teaching is only moderate in amount, and in the direction of the professor's own work, there is no stimulus so great as that which the association with a class of earnest students supplies" (p. 280). "Men of affairs should resign the endowments intended for the maintenance of scholars to those whose zeal is sufficient to induce them to make gladly the sacrifices which the advancement of knowledge usually entails" (p. 277).

Mr. Euward Saunders writes as follows to the September number of the Entomologist's Monthly Magazine, under date August 6, on the subject of "Dead Humblc-bees under Lime Trees." Dead humble bees, more or less mutilated, have often been observed in large numbers under lime trees, and various suggestions have been offered to account for their presence in such a position. Some observations which I was able to make the other day suggest the probable reason for the death and evisceration of such becs, anci, therefore, may be worth record. ing. While walking on Hayes Common, Kent, on the $3 \mathrm{rd}$ of this month, I noticed, under a large spreading lime trce, in full flower, that the ground was strewn with bodies of humble-bees of several species ; I and one of my children picked up a number of them, and found several still moving their legs, and evidently only quite recently mutilated, nearly every specimen appearing to have been killed in the same manner, having a large hole in the upper surface of the thorax, and another at the apex of the abdomen, the apical segments being removed; thinking that it would be a good opportunity to try and find out who or what was the cause of their death, I sat down close to the tree and watched. The tree was covcred with bloom, and hive-bees and humble-bees abounded, but I could not see any wasps, so I at once abandoned the idea that they wcre the culprits, as some have thought probable; everything secmed peaccable, and for some time I could see no possible enemy to suspect. At last, I saw among the higher branches a bird, and from the exact spot where it was fidgeting about down dropped a carcase of a bee. $I$ at once picked it up, and found the legs still twitching convulsively; although 1 did not actually see the bird drop the bee, I think there can be little doubt that it did. I went back again, and sat down to try and discover what bird it was, and after a little time a bird, which was in all probability the same, although I had lost sight of it while examining the bee, came out into a less leafy part of the tree, and I was able to identify it as a great tom-tit; and although I have no positive evidence whereby to convict Parus major, I think the probabilities of his being the culprit are so strong, that it is hardly necessary to seek further for the murderer of these humble innocents.

ADVICES received by the last mail from Iceland state that the weather in the island during the summer has, in common with everywhere else in North Europe, been very cold and stormy. Even in the midale of July night-frosts occurred frequently in the higher-lying districts, and sometimes also by the coast. The grazings have suffered greatly in consequence of the weather, being in many places in a miserable state. During Junc and
July severe storms devastated the island, killing the sheep in many places, notably in the Westfjord. The fishing has been fairly good in some places whcre the herring have been plentiful this summer. The fish was fat and in excellent condition.

ON the west coast of Norway, too, very unusual weather has becn experienced this summer, snow having fallen in several places, whilst night-frosts have injured the crops. Tourists from the interior state that they never have experienced so backward a season in that part. The cold weather is being ascribed to the cnormous ice-masses which have descended from the Polar regions into the Gulf Stream in the spring, and the large quantity of drift ice in motion to the north and north-east of Norway.

Inted Ligence received from North and Central Sweden states that the migratory birds are already leaving in large numbers. Between August 16 and 18 thousands of wildfowl were seen passing over Stockholm, their progress lasting for hours at the time. During the night, too, their calls were heard. That the birds have previously left their summer haunts so early is unknown.

A QUick change of temperalure arrived on the U.S. Atlantic coast on the afternoon of August 25, the mercury falling $40^{\circ}$. A hurricane along the Florida and Caroline coasts accompanied it, causing serious damage. Charleston, South Carolina, had one fourth of its houses unroofed; church steeples were blown down and the wharves were overflowed and damaged, the wind blowing at the rate of scventy miles per hour. The hotels and summer-houses on Sullivan's Island were partly destroyed. The damage is reported to amount to $\$ \mathrm{I}, 000,000$. Savannah reports serious Iosses from the overflow and the wind. Jacksonville and and Fernanlina, Florida, report heavy losses with wrecked vessels. The storm, which extended northward with less severity, was general along the Atlantic coast.

AT the last meeting of the Asiatic Society of Japan (reported in the Fapan Mail) a paper by Mr. H. Pryer was read on the relation between the Lepidoptera of Great Britain and Japan. From the statistics given it appears that about $\mathbf{x} 6$ per cent. of the British species are found in Japan. At first sight there does not seem to be any strong resemblance between the Japanese and British spccimens of certain species; but the differences are demonstrably due simply to the effect of temperature. In Japan the temperature forms are very numerous, because of the fluctuations in temperature which are so peculiar to the country. When the great distance separating the countries and the striking climatic differences are considercd, the identity of such a large percentage of species is a fact of the highest intcrest to the entomologist.

The syllabus of the day and evening classes of the Mason Science College, Birmingham, for the session 1885.86 has been published.

THE Asiatic Society of Bengal has just issued a centenary review of the work accomplished by it. The first meeting of the Society took place during the Governor-Generalship of Warren Hastings, in the year 1784 .

IT is stated that various lines of telegraphs are to be constructed in Corea under the superintendence of Chinese officials. The preliminary surveys have already been commenced between Gensan and Seoul, and at various points on the Chino-Corean frontier. The length of the lines actually undertaken is over 400 miles.

THE recent earthquakes in Java appear to have extended all over the Eastern Archipelago. The official journal of Batavia contains a report from the Government resident at Amboyna stating that on April 30 violent shocks were felt at Amboyno, in 
Banda, and Kayeli, and on the following day at Kairatu. Villages on the beach were overwhelmed by the sea. At intervals of about twenty minutes the sea receded to a distance of 300 yards from low water mark, and then returned to overflow to a depth of 34 feet the broad plain near the beach, fifteen miles west of Kayeli. This phenomenon does not appear to have been general, but to have confined itself to the locality mentioned.

EARTHQUake shocks were felt on August 26 in the valley of the little river Mürz, in Styria. They caused no damage beyond loosening the foundations of a few cottages. Several shocks were felt in the same district last May.

THE Nacion of Guayaquil gives details of the eruption of the volcano of Cotopaxi early on the morning of July 23. It states that about one o'clock in the morning people were awakened by a sound as of heavy artillery fire, apparently from guns of the heaviest calibre. The explosions followed one another with wonderful rapidity, sometimes causing a continuous roar, shaking the earth and causing the windows and the doors of the houses to rattle. At Chimbo, which is situated almost at the foot of the volcano, there was what the residents along the river Yana. Yacu call an "aluvion." The phenomenon so-called is really the stream of lava which descends the mountain sides, melting the snow with which it is covered, and pouring down a tremendous mass of lava, mud, stones, and all obstacles encountered in its progress. Investigations during the day showed that the shocks produced by the explosions during the night were exceedingly heavy. The smoke hung like a pall over the face of the country, and the steady fall of ashes thrown constantly out of the terrible crater intensified the darkness. Accounts from Latacunga state that the eruption began with a terrible storm. The damage done was considerable, but the number of victims is not known A similar catastrophe occurred in June 1877 .

THE “ Bureau Scientifique Central Néerlandais," established in 1871 at Haarlem, after the death of its first Director, the $1_{\text {amented Prof. E. H. von Baumhauer, has been taken in hand }}$ by Dr. P. P. C. Hoek, at Leiden. The Bureau is in relation with the Smithsonian Institution, Washington, the "Ministère de l'Instruction publique en France," the "Commission des Echanges Internationaux à Bruxelles," with bureaus in Christiania, Stockholm, Copenhagen, \&c. Packages sent as donations or exchanges, and destined for Dutch learned societies or scientists, henceforth are to be sent to the new Director at Leiden or to be delivered to the agent of the Bureau at London free of expense. The agents of the Bureau are Messrs. Williams and Norgate, I4, Henrietta Street, Covent Garden, London.

THE additions to the Zoological Society's Gardens during the past week include a Macaque Monkey (Macaius cynomolgus $\$$ ) from India, presented by Mr. H. J. Thimbleby; a Binturong (Arctictis binturong of) from Malacca, presented by Mr. T. H. Haynes; a Great Kangaroo (Macropus giganteus) from $\mathrm{New}$ South Wales, presented by Mr. A. McIlwraith; two Goldencrowned Conures (Conurus aureus) from South-East Brazil, presented by Mr. Cuthbert D. Middleton; a Common Cuckoo (Cuculus canorus), British, presented by Mr. R. B. Spalding; two Javan Sparrows (Padda oryzivora) from Java, presented by Miss Coleman; a Black-headed Gull (Larus rubicundus), European, presented by Mr. Humphries; a Horned Lizard (Phrynosoma cornutum) from Texas, presented by Miss Simpson; a Common Chameleon (Chamoleon vulgaris) from North Africa, presented by Master Cecil Guy Dart; a Robben Island Snake (Coronella phocarum) from Robben Island, South Africa, presented by the Rev. G. H. R. Fisk, C.M.Z.S. ; a Macaque Monkey (Macacus cynomolgus) from Inclia, a Siamese Blue Pie (Urocissa magnirostris) from Siam, an American Black Snake
(Coluber guttatus) from North America, a Smooth-headed Capuchin (Cebus monachus), a Squirrel Monkey (Chrysothrix sciurea) from South America, deposited ; two Axolotls (Siredon mexicanus) from Mexico, purchased; fourteen Striped Snakes (Tropidonotus sirtalis), born in the Menagerie.

\section{ASTRONOMICAL PHENOMENA FOR THE WEEK, I885, SEPTEMBER 6-12}

(FOR the reckoning of time the civil day, commencing at Greenwich mean midnight, counting the hours on to 24 , is here employed.)

\section{At Greenwich on September 6}

Sun rises, 5 h. $22 \mathrm{~m}$.; souths, $11 \mathrm{hh}$. $58 \mathrm{~m} .8 .3 \mathrm{~s}$.; sets, 18h. $34 \mathrm{~m}$. decl. on meridian, $6^{\circ} 18^{\prime}$ N.: Sidereal Time at Sunset, I 7h. $38 \mathrm{~m}$.

Moon (New on September 8) rises, 2h. IIm, ; souths, $9 \mathrm{~h} .44 \mathrm{~m}$. sets, $17 \mathrm{~h} .6 \mathrm{~m}$. ; decl. on meridian, $14^{\circ} 3^{\prime} \mathrm{N}$.

$$
\begin{aligned}
& \text { Planet Rises Souths Sets Decl.onmeridian }
\end{aligned}
$$

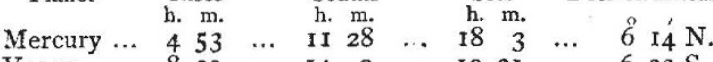

$$
\begin{aligned}
& \begin{array}{lllllllllllllll}
\text { Venus } & \ldots & 8 & 29 & \ldots & 14 & 0 & \ldots & 19 & 31 & \ldots & 6 & 23 & \mathrm{~S} .
\end{array}
\end{aligned}
$$

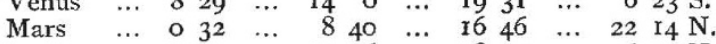

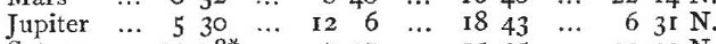

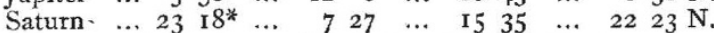

$$
\begin{aligned}
& \text { * Indicates that the rising is that of the preceding day. }
\end{aligned}
$$

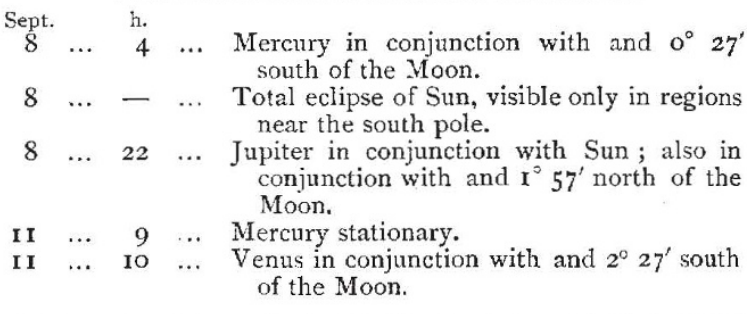

\section{GEOGRAPHICAL NOTES}

Mr. Gardner, British Consul at Newchwang, publishes with his annual trade report this year (China, No. 6, I885) a most interesting account of his consular district, which embraces the whole of Manchuria. It contains an area of about 300,000 square miles and a population estimated by the Roman Catholic missionaries at $15,000,000$. Its boundaries are, on the north, the Amour, separating it from Eastern Siberia, on the east the Ussuri River and Sihoti Mountains separating it from the Russian province of Primorsk, on the south the Tiumen and Yalvo Rivers separating it from Corea, the Yellow Sea and the Gulf of Liao-tung, on the west China, Mongolia, and Russian Siberia. The first part of the report deals with the ordinary trade and productions of Manchuria, and gives a summary of the statistics of foreign trade since the port of Newchwang was opened to trade in I86r. The second part is devoted to geographical notes on Manchuria, its three provinces, Heh-lung-Kiang (or Sagalien), Kirin and Fêngtien being taken separately. The history, government, military force, and divisions in towns are the heads under which these provinces are described. Various appendices contain an account of a journey from Moukden to San-sing, an essay on Christian missions in Manchuria, and a sketch of the botany of South Manchuria by Dr. Morrison. The latter is, from a scientific point of view, the most important part of the report. The lists given are defective, as the greater part of Dr. Morrison's collections remain unidentified, there having been no opportunity of visiting herbaria or consulting published accounts of Northern Chinese plants.

THE report of the Resident in the State of Selangore in the Malay peninsula for the past year contains some curious information with regard to "aboriginal tribes" called the Sakeis, who number between 700 and 800 . They are in nine divisions, under head-men called Batins, and they live mainly by collecting gutta, rattans, and other jungle produce. As far as is known they have no form of religious worship, but they are very superstitious, believing in good and bad omens, the sacred character of certain birds, and they always desert a village as unlucky on the death of any member of the tribe. They tattoo figures on their arms, but apparently only for the sake of ornament, and 